\title{
Decomposition of Single-use Products Made of Bioplastic under Real Conditions of Urban Composting Facility
}

\author{
Anna Báreková' ', Martina Demovičová', Lucia Tátošová1, \\ Lucia Danišová2, Elena Medlenová2, Slávka Hlaváčiková \\ 1 Department of Landscape Planning and Land Consolidation, Faculty of Horticulture and Landscape \\ Engineering, Slovak University of Agriculture in Nitra, ul. Hospodárska 7, 94976 Nitra, Slovakia \\ 2 Department of Plastics, Rubber, and Fibres, Faculty of Chemical and Food Technology, Slovak Technical \\ University in Bratislava, Radlinského 9, 81237 Bratislava 1, Slovakia \\ * Corresponding author's e-mail: anna.barekova@gmail.com
}

\begin{abstract}
According to Directive (EU) 2019/904 of the European Parliament and of the Council of 5 June 2019, singleuse plastic cutlery, cotton buds, straws and stirrers will be banned in the member states of EU from summer 2021 onwards. Many of them are being replaced by compostable products. The aim of the research was to assess the biological disintegration of selected single-use products under real conditions of urban composting facility. All tested products are established for the Slovak market as $100 \%$ compostable by a composting facility. The eight selected products from five different producers were placed into a composting pile of the urban composting facility for 12 weeks. The samples were visually inspected on a regular basis. Temperature and humidity of the pile were continuously measured at the same time. Three samples from each kind of tested product were analyzed, 3 pieces of filter paper were used as the reference samples. The research showed that all tested products were completely or partially disintegrated during the considered period. The average degree of the disintegration of $90 \%$ was not reached for one producer only.
\end{abstract}

Keywords: bioplastics, disintegration, compost, composting facility, single-use products.

\section{INTRODUCTION}

Plastics have become an indispensable commodity in today's life due to their wide range of applications, particularly in packaging [Groh et al., 2019]. The threat of plastic pollution has mobilized global governments, business corporations, and local communities to combat against its proliferation in the environment [Schnurr et al., 2018]. Social, technological, and institutional amendments like nationwide phasing out of single-use plastics, resolutions by businesses and corporations to reduce their plastic footprint, initiatives by non-profit organizations to clean up beaches and ocean, behavioural changes in public to reduce the consumption and littering of single-use plastics have raised hope of positive changes in the recent past [Heidbreder et al., 2019; Moore, 2015; Xanthos and Walker, 2017].
The announcement of plastic pollution as a worldwide crisis by the United Nations in 2017 [UNEP, 2017] has made several businesses establishments to adjust their corporate strategies, preparing for an accelerated transition to a circular economy. Bioplastics are promoted as an alternative to the conventional petroleum-based non-biodegradable plastics. With a production volume of 2.11 million tons in 2019, their market share is very low ( $1 \%$ of all plastics) but expected to increase in the future [European Bioplastics, 2019]. The term "bioplastics" is still ill-defined. It includes the materials made from renewable feedstocks, the materials supposed to degrade naturally (biodegradable), or both. It is currently unclear whether the plant-based materials which are often blended with synthetic materials (e.g., cellulose, and bamboo-based materials) fall under 
that category. Either way, they are produced to fulfil the same function as plastic materials and appear as such to the consumer [Zimmermann et al., 2020]. The new circular economy action plan adopted in March 2020 [EC, 2020], commits the European Commission to develop a policy framework on the sourcing, labelling and use of biobased plastics and on the use of biodegradable or compostable plastics, including their labelling.

Although biodegradable polymers have been commercialized for over 30 years, this niche market is beset with a variety of roadblocks led by high prices and lack of an industrial infrastructure to deal with these materials [Vaverkova and Adamcova, 2015, Czech et al. 2013]. Industrial composting appears to be an expected and preferred way of the disposal/recovery of such materials [Sedničková et al., 2018]. Compostable materials certified for industrial composting (EN13432) achieve min. 90\% disintegration under laboratory conditions at $58^{\circ} \mathrm{C}$ in 90 days. That means $10 \%$ of dry weight allowed to be retained by $2 \mathrm{~mm}$ sieve [Song et al., 2009].

Our research was focused on evaluating the degradability of bioplastic packaging under real conditions of the urban composting facility. The tested products are commonly available on the market and labelled as compostable. Scientific publications routinely observe the behaviour of biodegradable polymers under laboratory conditions simulating the composting process. On the other hand, the research of biodegradable municipal waste (BMW) which is conducted under the real conditions of a local processor, is still very rare, not only in Slovakia. The laboratory conditions cannot simulate all the factors affecting the process of the disintegration. For this reason, this kind of research is necessary and irreplaceable for municipal waste management.

\section{MATERIAL AND METHODS}

The research was conducted in the urban composting facility in Krškany (Nitra District, Southwest Slovakia). In this place, the BMW produced by family house gardens and public greenery located in the territory of the city of Nitra are processed. Our procedure was based on the certified methodology "Methodology for evaluation of degradation of degradable polymer materials in real composting environment" [Vaverková et al., 2014]. According to specific conditions, it was necessary to partially modify the methodology. At the beginning, the examined product samples were photographically documented, and the initial weight of each sample was recorded. A cellulose unreinforced filter paper with a diameter $15 \mathrm{~mm}$ was used as the reference sample. Each product was tested in three identical samples; the disintegration of 8 products made by 5 producers was monitored. The detailed overview is listed in Table 1.

Table 1. Characteristic of samples

\begin{tabular}{|c|c|c|c|c|c|c|}
\hline Producer & Sample & Use & Type & $\begin{array}{l}\text { EAN cod / } \\
\text { specification }\end{array}$ & Biodegradation & Certification \\
\hline $\mathrm{Na}: \mathrm{Pac}$ & $\begin{array}{l}\mathrm{Al} \\
\mathrm{A} 2 \\
\mathrm{~A} 3\end{array}$ & bowl & sugar-cane / PLA & CRL050 & $\begin{array}{l}\text { Industrial } \\
\text { composting }\end{array}$ & \begin{tabular}{|l} 
Patent \\
ZL200480010476.8
\end{tabular} \\
\hline $\mathrm{Na}: \mathrm{Pac}$ & $\begin{array}{l}\text { B1 } \\
\text { B2 } \\
\text { B3 } \\
\end{array}$ & lid & cellulose / sugar-cane & CR1002 & $\begin{array}{l}\text { Industrial } \\
\text { composting }\end{array}$ & $\begin{array}{l}\text { Patent } \\
\text { ZL200480010476.8 }\end{array}$ \\
\hline Eco-Product & $\begin{array}{l}\text { C1 } \\
\text { C2 } \\
\text { C3 }\end{array}$ & lid & PLA & 644632902600 & \begin{tabular}{|l|} 
Industrial \\
/ home \\
composting
\end{tabular} & $\begin{array}{l}\text { ASTMD6400, } \\
\text { D6868, BPI }\end{array}$ \\
\hline Biotrem & \begin{tabular}{|l} 
D1 \\
D2 \\
D3
\end{tabular} & plate & wheat bran & 5905279376007 & $\begin{array}{l}\text { Industrial Home } \\
\text { composting }\end{array}$ & EN 13432 \\
\hline Biotrem & \begin{tabular}{|l|} 
E1 \\
E2 \\
E3 \\
\end{tabular} & fork & $\begin{array}{l}\text { PLA / wheat bran } \\
(10 \%)\end{array}$ & 5905279376366 & $\begin{array}{l}\text { Industrial } \\
\text { composting }\end{array}$ & EN 13432 \\
\hline Naturesse & $\begin{array}{l}\text { F1 } \\
\text { F2 } \\
\text { F3 } \\
\end{array}$ & fork & CPLA & CPLA14162 & $\begin{array}{l}\text { Industrial } \\
\text { conposńng }\end{array}$ & EN 13432 \\
\hline Vegware & $\begin{array}{l}\text { G1 } \\
\text { G2 } \\
\text { G3 }\end{array}$ & plate & sugar-cane & 5060271922314 & $\begin{array}{l}\text { Industrial } \\
\text { composting }\end{array}$ & $\begin{array}{l}\text { TUV AUSTRIA, } \\
\text { BPI }\end{array}$ \\
\hline Yegware & $\begin{array}{l}\mathrm{H} 1 \\
\mathrm{H} 2 \\
\mathrm{H} 3 \\
\end{array}$ & soup bowl & cellulose board / PLA & 5060271920280 & $\begin{array}{l}\text { Industrial } \\
\text { composting }\end{array}$ & $\begin{array}{l}\text { TUV AUSTRIA, } \\
\text { BPI }\end{array}$ \\
\hline $\begin{array}{l}\text { Papirna } \\
\text { Perstejn s.r.o. }\end{array}$ & $\begin{array}{l}11 \\
12 \\
13\end{array}$ & filter paper & cellulose & 624880104150 & - & ISO 9001 \\
\hline
\end{tabular}


The samples marked with number 3 (i.e., A3, B3, C3 ...) were encapsulated in a plastic net with a $2 \times 2 \mathrm{~mm}$ mesh diameter. The remnant samples (numbered 1 and 2) were packed in a fiberglass net case/pack with a $4 \times 4 \mathrm{~mm}$ mesh diameter. The prepared samples were then inserted and fixed between two layers of a test plastic-covered net. The net with samples had a size of $1 \times 2 \mathrm{~m}$ and the $10 \times 10 \mathrm{~mm}$ mesh diameter (Figures 1 and 2).

The composting pile with a volume of approx. $11 \mathrm{~m}^{3}$ placed in a box with a lid was formed by a homogeneous mixture of the following three types of fresh BMW:

- wood chips $\left(10 \%_{\text {vol }}\right)$,

- waste from the gardens of family houses collected in bio-containers $\left(50 \%{ }_{\mathrm{vol}}\right)$,

- grass from public greenery $\left(40 \%{ }_{\text {vol }}\right)$.

On 6 July 2019, the net with the samples was inserted into the composting pile. Approx. $60 \%$ vol of the prepared substrate was situated under the net and the rest of the composting stack was used to cover the tested samples (Figure 3).

Throughout the whole research, the 3 measuring probes (no. 1, 2, and 3) were placed directly under the tested net for the measurement of

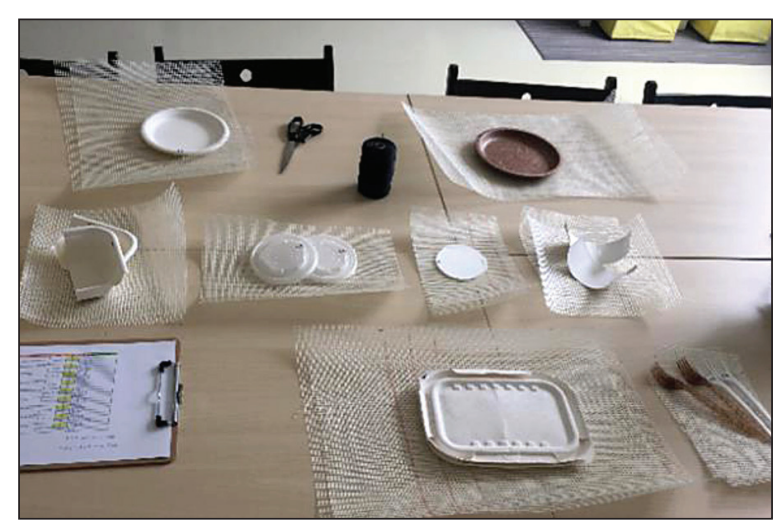

Figure 1. Preparation of samples for packaging

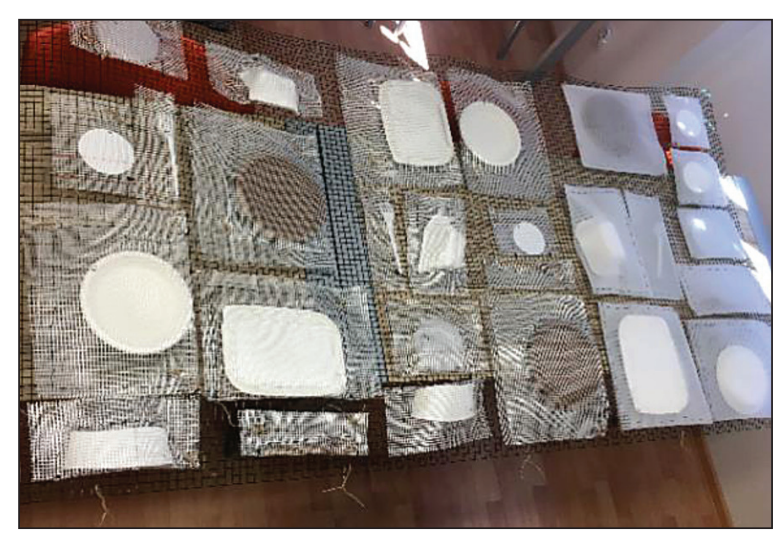

Figure 2. Prepared net with samples temperature and humidity of the substrate. Simultaneously, the probe no. 4 measured the outside air temperature. The measured values were recorded by the datalogger at hourly intervals. The average values of temperature and humidity for each week of the experiment were calculated from the data obtained by measuring probes 1,2 and 3 . The diagram in the Figure 4 shows the development of the substrate humidity. The average value of humidity for the entire monitored period was $35 \%{ }_{\text {vol }}$.

The diagram in the Figure 5 shows the temperature development of the substrate and exterior. The average value of temperature for the entire monitored period was $62.6^{\circ} \mathrm{C}$. The outside air temperature (measured using probe no. 4) amounted to $22^{\circ} \mathrm{C}$, on average.

After the set period (12 weeks), the tested material was removed from the test net. Afterwards, it was cleaned from the compost and dried before the final measurement of the weight. The resulting values of the sample remnants weight were recorded and compared with the initial weight values. The disintegration degree of the individual samples was quantified by the following formula:

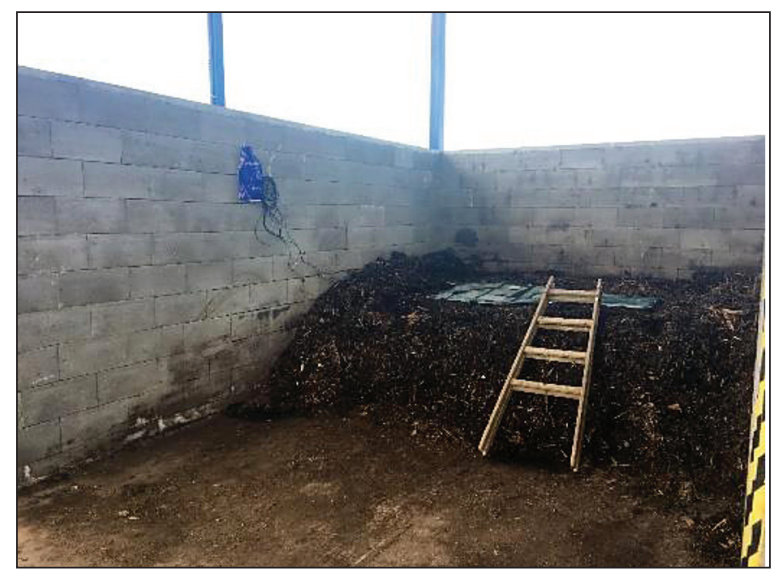

Figure 3. Placement of samples in the compost pile

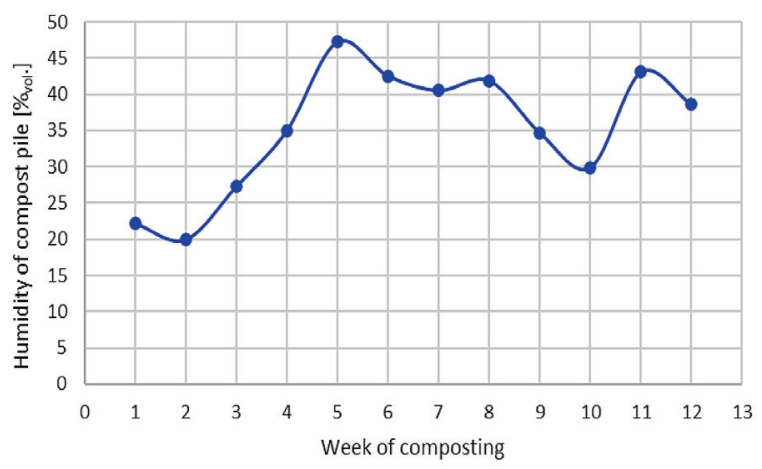

Figure 4. Average weekly humidity of compost pile for the experimental period 


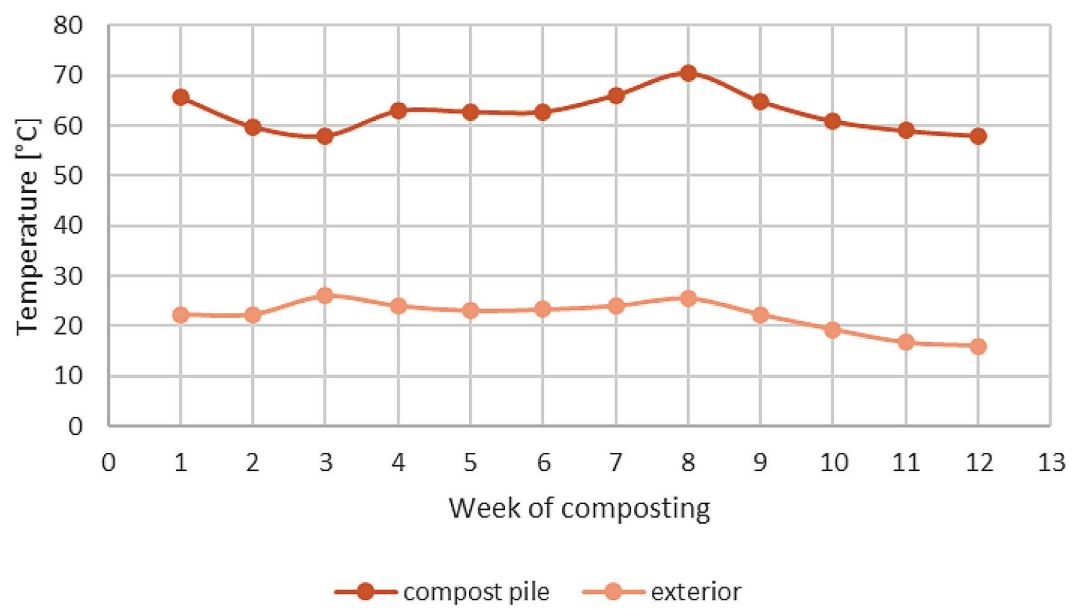

Figure 5. Average weekly temperature in compost pile and exterior for the experimental period

$$
D(\%)=\frac{M i-M r}{M i} \times 100
$$

where: $D$ - degree of disintegration (\%),

$M i$ - sample weight at the beginning of the experiment $(\mathrm{g})$,

$M r$ - sample weight at the end of the experiment $(\mathrm{g})$.

\section{RESULTS AND DISCUSSION}

During the 84 days of the study, 8 inspections were performed, including the start and the end of the experiment. The detailed itemization of the entire experiment development is listed in the Table 2 . The table shows the average values of temperature and humidity on the controlled day including the days of the composting substrate digging.

\section{Disintegration of the samples packed into the net with the $4 \times 4 \mathrm{~mm}$ mesh diameter}

Total number of the samples A to I numbered 1-2 (see Table 1) was 18 (including filter papers).
The resulting values of the weights before and after the experiment are listed in the Table 3. The degree of disintegration was calculated using the Eq. (1).

The Na:Pac caps (i.e. samples B1 and B2) are the only ones which did not achieve the required degree of the $90 \%$ disintegration throughout the monitored period (see Figure 6). The weight loss of the caps was only $0.63 \%$ which is less than the required limit. The remaining test samples exceeded the value of $90 \%$ disintegration. The disintegration degree of these samples in the nets with the $4 \times 4 \mathrm{~mm}$ mesh diameter in 12 weeks was sufficient. Both reference filter paper samples (I1 and I2) were disintegrated in $100 \%$.

\section{Disintegration of the samples packed into the net with the $2 \times 2 \mathrm{~mm}$ mesh diameter}

All tested samples A to I marked with the number 3 had a $2 \times 2 \mathrm{~mm}$ mesh package (see Table 1). The Table 4 shows the resulting values of the measured weights before and after the experiment. The results demonstrate that the remnants from the three brands have stayed on the $2 \times 2 \mathrm{~mm}$

Table 2. Experiment schedule of works

\begin{tabular}{|l|c|c|c|c|c|c|}
\hline \multicolumn{1}{|c|}{ Date } & $\begin{array}{c}\text { Time from } \\
\text { start (day) }\end{array}$ & $\begin{array}{c}\text { Sample } \\
\text { checking }\end{array}$ & $\begin{array}{c}\text { Digging } \\
\text { compost pile }\end{array}$ & $\begin{array}{c}\text { Average } \\
\text { temperature of } \\
\text { compost pile }\left({ }^{\circ} \mathrm{C}\right)\end{array}$ & $\begin{array}{c}\text { Average humidity } \\
\text { of compost pile } \\
\left(\% \%_{\text {vo }}\right)\end{array}$ & $\begin{array}{c}\text { Average exterior } \\
\text { temperature }\left({ }^{\circ} \mathrm{C}\right)\end{array}$ \\
\hline 6 July & 0 & $\begin{array}{c}\text { Start-up of } \\
\text { the test }\end{array}$ & & 50.8 & 11.1 & 26.5 \\
\hline 12 July & 7 & $\checkmark$ & $\checkmark$ & 64.2 & 19.9 & 20.1 \\
\hline 20 July & 15 & $\checkmark$ & & 42.2 & 15.4 & 26.1 \\
\hline 2 August & 28 & $\checkmark$ & & 56.3 & 40.4 & 22.2 \\
\hline 16 August & 42 & $\checkmark$ & $\checkmark$ & 56.5 & 35.5 & 20.5 \\
\hline 30 August & 56 & $\checkmark$ & & 62.2 & 36.0 & 27.3 \\
\hline 13 September & 70 & $\checkmark$ & & 52.5 & 31.4 & 21.1 \\
\hline 27 September & 84 & End of test & & 49.7 & 24.3 & 15.4 \\
\hline
\end{tabular}


Table 3. Weight of samples before and after composting and the disintegration degree of these samples in the nets with the $4 \times 4 \mathrm{~mm}$ mesh diameter

\begin{tabular}{|l|c|c|c|c|c|c|c|c|}
\hline \multicolumn{1}{|c}{ Producer } & \multicolumn{2}{c}{ Na:Pac } & $\begin{array}{c}\text { Eco- } \\
\text { product }\end{array}$ & \multicolumn{2}{c}{ Biotrem } & Naturesse & Vegware \\
\hline Samples & $\mathrm{A} 1+\mathrm{A} 2$ & $\mathrm{~B} 1+\mathrm{B} 2$ & $\mathrm{C} 1+\mathrm{C} 2$ & $\mathrm{D} 1+\mathrm{D} 2$ & $\mathrm{E} 1+\mathrm{E} 2$ & $\mathrm{~F} 1+\mathrm{F} 2$ & $\mathrm{G} 1+\mathrm{G} 2$ & $\mathrm{H} 1+\mathrm{H} 2$ \\
\hline $\begin{array}{l}\text { Weight at the beginning of the } \\
\text { experiment (g) }\end{array}$ & 13.65 & 40.55 & 10.08 & 139.28 & 15.66 & 10.21 & 21.38 & 8.59 \\
\hline $\begin{array}{l}\text { Weight at the end of the } \\
\text { experiment (g) }\end{array}$ & 0.99 & 4.31 & 0 & 3.78 & 0 & 0 & 0 & 0 \\
\hline Degree of disintegration (\%) & $\mathbf{9 2 . 7 3}$ & $\mathbf{8 9 . 3 7}$ & $\mathbf{1 0 0}$ & $\mathbf{9 7 . 2 9}$ & $\mathbf{1 0 0}$ & $\mathbf{1 0 0}$ & $\mathbf{1 0 0}$ & $\mathbf{1 0 0}$ \\
\hline
\end{tabular}
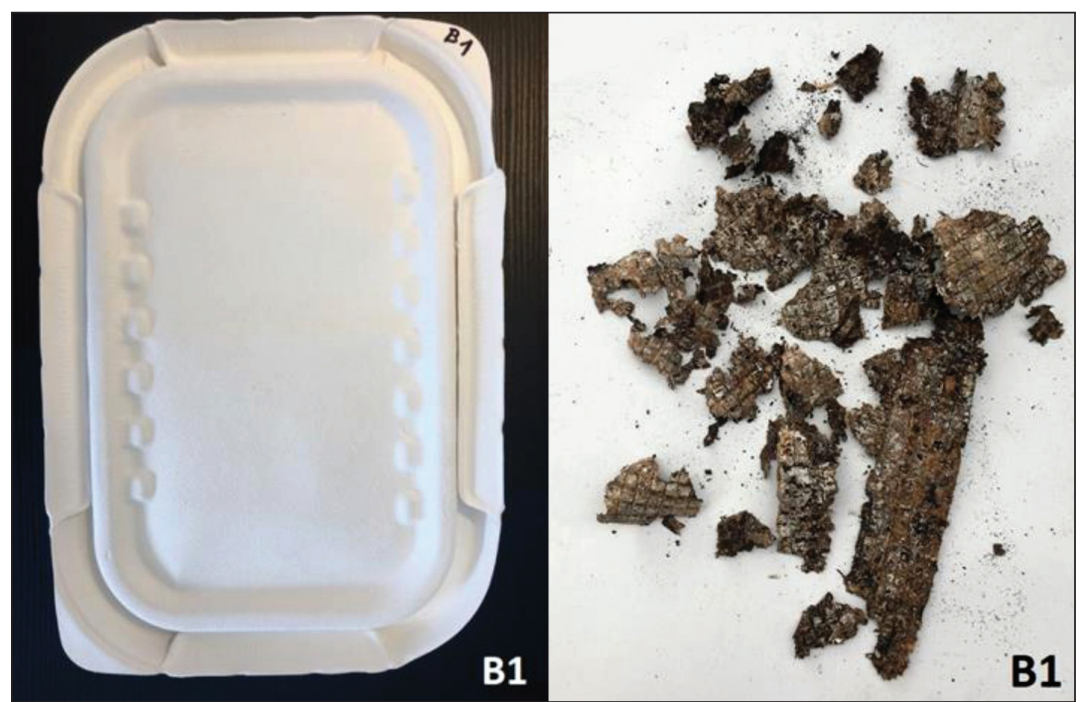

Figure 6. Sample B1 (Na:Pac) before and after degradation in the compost pile

mesh. The lid and the bowl from the Na:Pac (samples A3 and B3) represented the smallest weight loss from all tested products. The lid made of cellulose and sugar cane (sample B3) had the worst resulting disintegration degree, only $34.28 \%$. The products of Vegware brand (samples G3 and H3) have not achieved the required 90\% disintegration limit in this type of the net, but the degree of disintegration still achieved a greater value than in the case of $\mathrm{Na}: \mathrm{Pac}$ products. The Biotrem plate (sample D3) made of wheat bran had the degree of disintegration lower than the 90\% limit only by $1.76 \%$. The reference sample of the filter paper (I3) disintegrated to $100 \%$. The figures 7 to 11 show the sample pictures of the products which have not achieved the required disintegration degree.

\section{Overall evaluation of the research results}

The results show that the certificated compostable substitutes for disposable plastics available on the market do not always demonstrate the compostability required for composting under real conditions of the urban composting facility. On the other hand, it is likely that the bioplastics would be exposed to mechanical influences during a conventional compost

Table 4. Weight of samples before and after composting and the disintegration degree of these samples in the nets with the $2 \times 2 \mathrm{~mm}$ mesh diameter

\begin{tabular}{|l|c|c|c|c|c|c|c|c|}
\hline \multicolumn{2}{|c}{ Producer } & \multicolumn{2}{c}{ Na:Pac } & $\begin{array}{c}\text { Eco- } \\
\text { product }\end{array}$ & \multicolumn{2}{c}{ Biotrem } & Naturesse & \multicolumn{2}{c|}{ Vegware } \\
\hline Samples & A3 & B3 & C3 & D3 & E3 & F3 & G3 & H3 \\
\hline $\begin{array}{l}\text { Weight at the beginning of the } \\
\text { experiment (g) }\end{array}$ & 10.99 & 22.43 & 5.02 & 73.1 & 7.95 & 5 & 11.19 & 5.22 \\
\hline $\begin{array}{l}\text { Weight at the end of the } \\
\text { experiment (g) }\end{array}$ & 2.86 & 14.74 & 0 & 8.6 & 0 & 0 & 8.82 & 1.02 \\
\hline Degree of disintegration (\%) & $\mathbf{7 3 . 9 9}$ & $\mathbf{3 4 . 2 8}$ & $\mathbf{1 0 0}$ & $\mathbf{8 8 . 2 4}$ & $\mathbf{1 0 0}$ & $\mathbf{1 0 0}$ & $\mathbf{7 4 . 7 7}$ & $\mathbf{8 0 . 5 6}$ \\
\hline
\end{tabular}




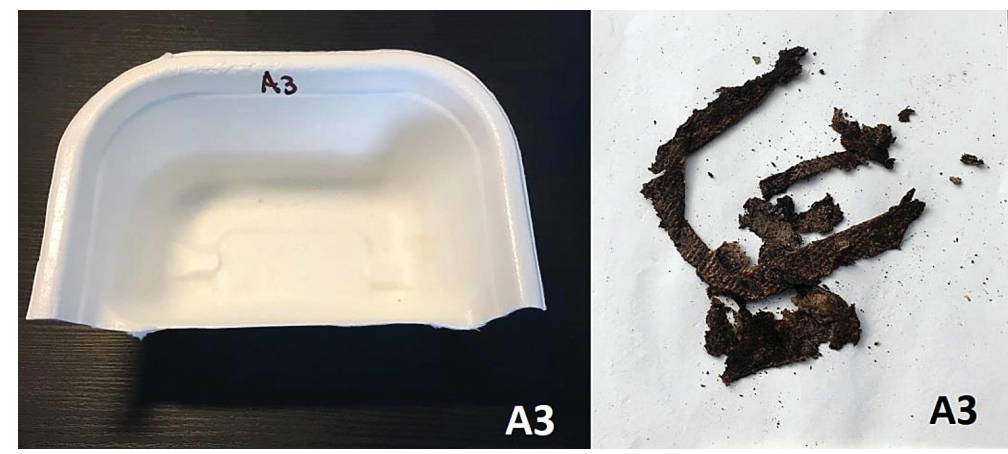

Figure 7. Sample A3 (Na: Pac) before and after degradation in the compost pile
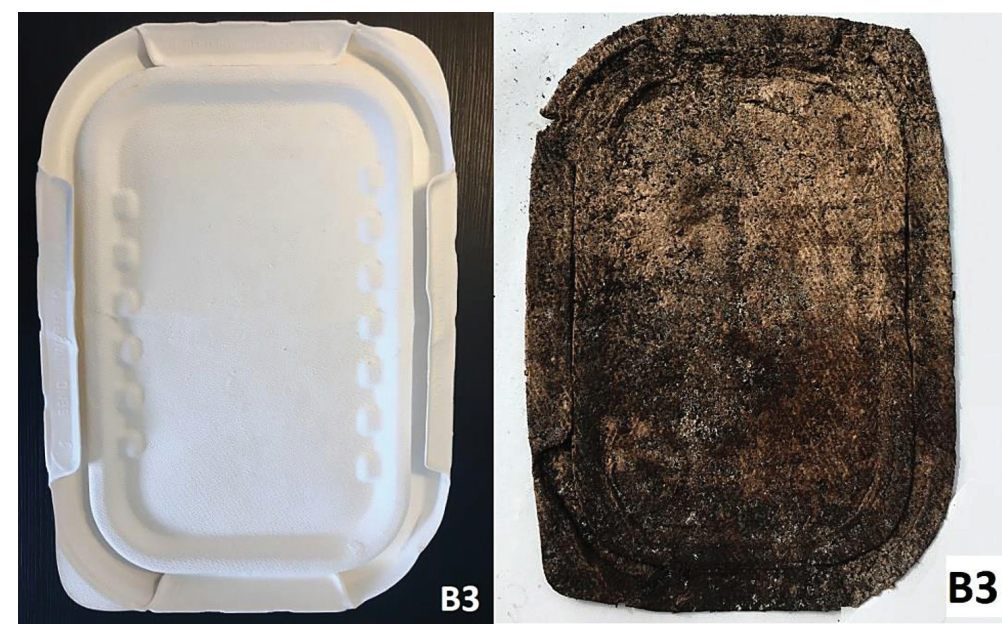

Figure 8. Sample B3 (Na: Pac) before and after degradation in the compost pile
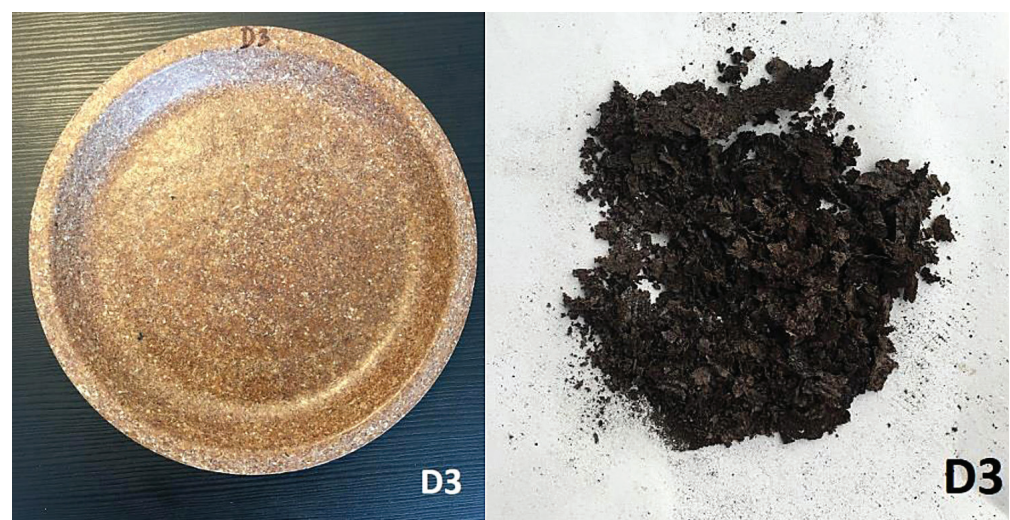

Figure 9. Sample D3 (Biotrem) before and after degradation in the compost pile
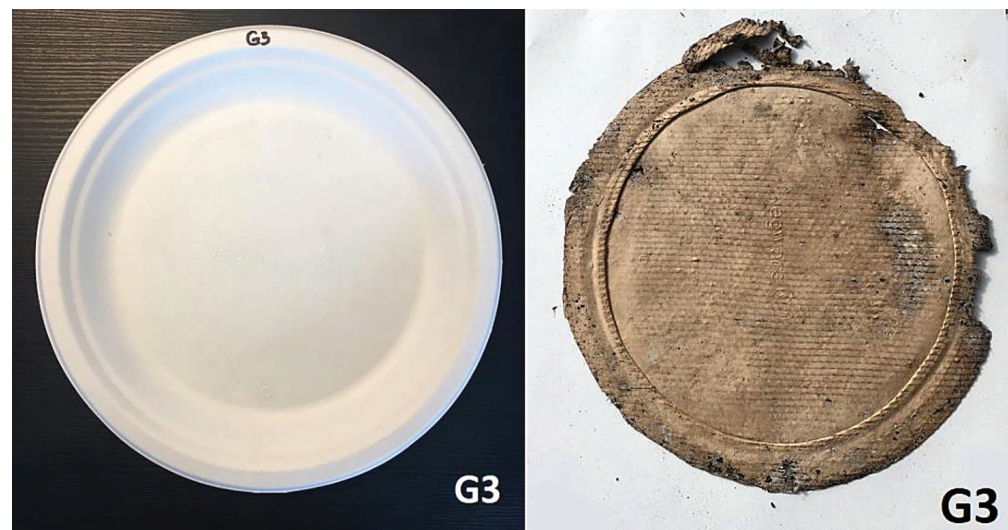

Figure 10. Sample G3 (Vegware) before and after degradation in the compost pile 

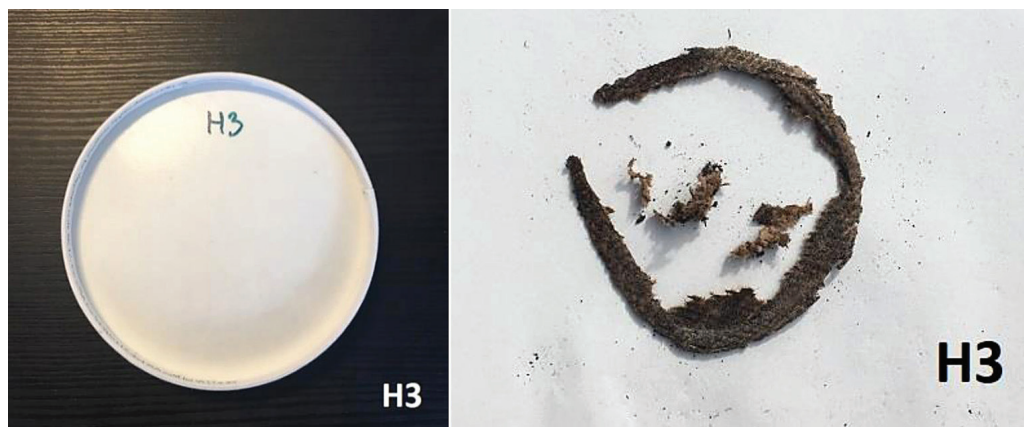

Figure 11. Sample H3 (Vegware) before and after degradation in the compost pile

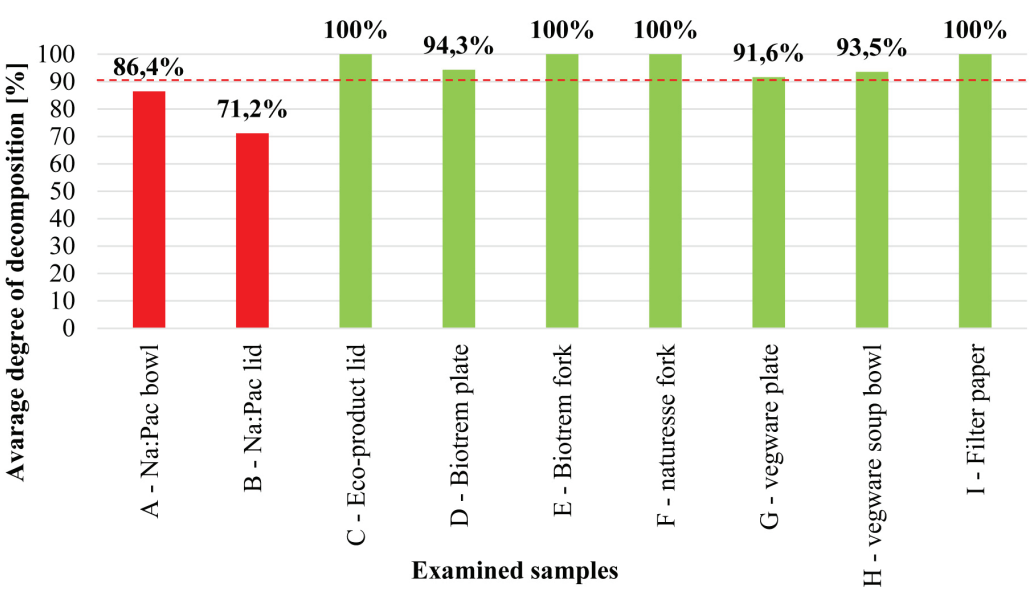

Figure 12. Average degree of decomposition of the examined samples (\%)

digging that would support the biodegradation and simultaneously the increase of the resulting disintegration degree. The diagram in Figure 12 shows the ultimate comparison of all tested products. The final percentage calculation of the average weigh losses includes all 3 samples of each product packed in the $2 \times 2 \mathrm{~mm}$ mesh, and in the $4 \times 4 \mathrm{~mm}$ mesh. The diagram shows that the minimum disintegration limit of $90 \%$ is reached by all examined products except the lids and the bowls of the Na:Pac brand. After the 12 weeks of the bioplastic's degradation by composting, each product has been partially or completely disintegrated. Although the Na:Pac brand products did not reach the required value, it is highly likely that in a longer period of time and under similar conditions in the substrate, the selected bioplastics would eventually disintegrate completely.

\section{CONCLUSIONS}

As many as 11 out of 18 samples (including the reference samples) completely disintegrated in the industrial composting pile in the composting facility in 12 weeks. The rate of the disintegration of individual compostable product types is different under real composting facility conditions and does not only depend on material composition of a specific product, but also on a composition of the composting pile and the used composting technology.

The Nitra city composting facility can process all tested products safely as all of the undisintegrated pieces are being separated during the sowing of the final compost and returned into the composting process. The application of a compost made from compostable bioplastics in soil is suitable only if it concerns the biobased biodegradable bioplastics.

In order to be able to control the processing of the products is necessary to implement the closed-loop system. The provider of single-use compostable products (dishes) is obligated to collect them after the using and hand them over for recovery to a determined composting facility. The replacement of single-use plastics by biodegradable bioplastics is conditioned by the introduction of uniform product labelling in the EU and a gigantic campaign to inform citizens about the impending changes and their significance. 


\section{Acknowledgments}

This work was supported by the Operational Program Integrated Infrastructure within the project: Demand-driven research for the sustainable and innovative food, Drive4SIFood 313011V336, cofinanced by the European Regional Development Fund.

\section{REFERENCES}

1. Czech Z., Wilpiszewska K., Tyliszczak B., Jiang X., Bai Y., Shao L. 2013. Biodegradable self-adhesive tapes with starch carrier. Int. J. Adhes Adhes., 44, 195-199.

2. Directive (EU) 2019/904 of the European Parliament and of the Council of 5 June 2019 on the reduction of the impact of certain plastic products on the environment

3. EC, 2020. Communication from the Commission to the European Parliament, the Council, the Economic and Social Committee and the Committee of the Regions - A new circular economy action plan for a cleaner and more competitive Europe $(\mathrm{COM}(2020)$ 98 final).

4. European Bioplastics, 2019. Bioplastics market data, https://www.european-bioplastics.org/market, Accessed 30 November 2020.

5. Groh, K.J., Backhaus, T., Carney-Almroth, B., Geueke, B., Inostroza, P.A., Lennquist, A., Leslie, H.A., Maffini, M., Slunge, D., Trasande, L., Warhurst, A.M., Muncke, J. 2019. Overview of known plastic packaging-associated chemicals and their hazards. Science of the Total Environment, 651, 3253-3268.

6. Heidbreder, L.M., Bablok, I., Drews, S., \& Menzel, C. 2019. Tackling the plastic problem: A review on perceptions, behaviors, and interventions. Science of the Total Environment, 668, 1077-1093.

7. Moore, C.J. 2015. How much plastic is in the ocean?
You tell me! Marine pollution bulletin, 92(1-2), 1-3.

8. Sedničková, M., Pekařová, S., Kucharczyk, P., Bočkaj, J., Janigová, I., Kleinová, A., Jochec-Mošková, D., Omaníková, L., Perd'ochová, D., Koutný, M., Sedlařík, V., Alexy, P., Chodák, I. 2018. Changes of physical properties of PLA-based blends during early stage of biodegradation in compost. International Journal of Biological Macromolecules, 113, 434-442.

9. Schnurr, R.E.J., Alboiu, V., Chaudhary, M., Corbett, R.A., Quanz, M.E., Sankar, K., Srain, H.S., Thavarajah, V., Xanthos, D., Walker, T.R. 2018. Reducing marine pollution from single-use plastics (SUPs): a review. Mar. Pollut. Bull., 137, 157-171.

10. Song, J.H., Murphy, R.J., Narayan, R., Davies, G. B.H. 2009. Biodegradable and compostable alternatives to conventional plastics. Phil. Trans. R. Soc. B, 364, 2127-2139.

11. UNEP. 2017. UN declares war on ocean plastic. United Nation Environment Programme, https:// www.unenvironment.org/news-and-stories/pressrelease/un-declares-war-ocean-plastic-0, Accessed: 19th November 2020.

12. Vaverková, M. D., Adamcová, D. 2015. Biodegrability of bioplastic materials in a controlled composting environment. Journal of Ecological Engineering, 16(3), 155-160.

13. Vaverková, M.D., Adamcová, D., Marada P., Havlíček Z. 2014. Methodology for evaluation of degradation of degradable polymer materials in real composting environment. Mendel University, Brno, 24 p. [in Czech].

14. Xanthos, D., Walker, T.R. 2017. International policies to reduce plastic marine pollution from singleuse plastics (plastic bags and microbeads): A review. Marine Pollution Bulletin, 118(1-2), 17-26.

15.Zimmermann, L., Dombrowski, A., Völker, C., Wagner, M. 2020. Are bioplastics and plant-based materials safer than conventional plastics? In vitro toxicity and chemical composition. Environment International, 145, December, 106066. 